\title{
福岡県におけるドック前立腺検診の現状と問題点
}

\author{
九州大学医学部泌尿器科学教室 (主任: 熊澤浄一) \\ 内藤 誠二 小藤 秀嗣 熊澤 浄一 \\ 九州厚生年金病院泌尿器科（部長：尾本徹男） \\ 尾本徹男 \\ 九州労災病院泌尿器科 (部長 : 伊東健治) \\ 伊東 健 治 \\ 北九州総合病院泌尿器科 (科長 : 畑地康助) \\ 畑地康助 \\ 健和会大手町病院泌尿器科（部長：清水保夫） \\ 清 水 保夫 \\ 新小倉病院泌尿器科（部長：横山譲二） \\ 横山譲 二 \\ 新日鐵八幡製鉄所病院泌尿器科（部長：永芳弘之） \\ 永芳, 弘之 \\ 原三信病院泌尿器科（院長：原 三信） \\ 鷺山和幸 \\ 九州中央病院泌尿器科（部長：長谷川淑博） \\ 長 谷川 淑 博 \\ 国立福岡中央病院泌尿器科（院長：平田耕造） \\ 森 田一喜 朗 \\ 福岡赤十字病院泌尿器科（部長：太田康弘） \\ 太田康弘 \\ 自衛隊福岡病院泌尿器科（医長：箕田 薫) \\ 箕田薫 \\ 聖マリア病院泌尿器科（部長：本村精二） \\ 本 村 精 二
}

\section{CURRENT STATUS AND PROBLEMS OF A SCREENING FOR PROSTATIC CANCER IN DOCK IN FUKUOKA PREFECTURE}

Seiji Naito, Shuji Kotoh and Joichi Kumazawa

Department of Urology, Faculty of Medicine, Kyushu University

(Director: Prof. J Kumazawa)

Tetsuo Omoto

Department of Urology, Kyushu Kosei-nenkin Hospital

(Chief: T. Omoto)

Kenji Itoh

Department of Urology, Kyushu Rohsai Hospital

(Chief: K. Itoh) 


\author{
Kousuke Hatachi \\ Department of Urology, Kitakyushu General Hospital \\ (Chief: K. Hatachi) \\ Yasuo Shimizu \\ Department of Urology, Kenwakai Ohtemachi Hospital \\ (Chief: Y. Shimizu) \\ Joji Yokoyama \\ Department of Urology, Shinkokura Hospital \\ (Chief: J. Yokoyama) \\ Hiroyuki Nagayoshi \\ Department of Urology, Shinnittetsu Yahata Hospital \\ (Chief: H. Nagayoshi) \\ Kazuyuki Sagiyama \\ Department of Urology, Hara Sanshin General Hospital \\ (Director: S. Hara) \\ Yoshihiro Hasegawa \\ Department of Uroloyg, Kyushu Central Hospital \\ (Chief: Y. Hasegawa) \\ Ichikiro Morita \\ Department of Urology, National Fukuoka Central Hospital \\ (Director: K. Hirata) \\ Yasuhiro Ohta \\ Department of Urology, Fukuoka Red Cross Hospital \\ (Chief: Y. Ohta) \\ Kaoru Minoda \\ Department of Urology, Self Defense Force Fukuoka Hospital \\ (Chief: K. Minoda) \\ Seiji Motomura \\ Department of Urology, Saint Mary Hospital \\ (Chief: S. Motomura)
}

We analyzed the current status and problems of a screeing for prostatic cancer (PCa) through a health examination in 12 hospitals in Fukuoka prefecture. From 1987 to 1991, a total of 16,126 subjects received this. The number of subjects who received this increased every year. In 5 hospitals in which such a screening is optional, however, only about $20 \%$ of subjects through a health examination received it each year. Furthermore, most of the subjects were in their $50 \mathrm{~s}$ or $40 \mathrm{~s}$. Those in their $70 \mathrm{~s}$ or more who are at higher risk for PCa rarely received such screening. PCa was detected in 6 subjects $(0.04 \%)$ (well differentiated adenocarcinoma: 3 , moderate differentiated adenocarcinoma: 3 ) in 5 years. Five were in stage $B$ and treated with radical prostatectomy and one was in stage $C$ and hormonal therapy was performed. The mean age of the 6 patients was 57.7 year old ranging from 51 to 66 . The incidence of PCa detected by a screening in dock increased with age. Prostate specific antigen (PSA) was considered to be more useful for detecting prostate cancer in dock as compared with digital examination (DRE), transrectal ultrasonography or prostatic acid phosphatase because of its relatively high sensitivity $(83.3 \%)$ and specificity $(84.8 \%)$. The incidence of PCa detected with combination of DRE and determination of PSA was $0.15 \%$ and significantly higher than that detected with DRE alone, $0.01 \%$.

These results suggest the need for enlightenment on $\mathrm{PCa}$ and the significance of a screening with combination of DRE and determination of PSA through a health examination for detecting early stage 
of PCa.

Key words: prostatic cancer, dock-screening, prostatic cancer screening

要旨：福岡県内の12施設を対象に, 1987年から1991年までの 5 年間にわたるドック前立腺検診の実態に ついて調査し，その現状と問題点について検討した，5年間のドック前立腺検診受診者総数は 16,126 名 で，年次別にみると年々増加の傾向にあった。しかし，希望者のみを前立腺検診の対象としている 5 施 設でみると，前立腺検診受診者はドック検診受診者の $20 \%$ 前後と低いレベルで 5 年間一定していた。し かも年齢階層別受診者数は 50 歳代, 40 歳代に多く, 前立腺癌好発年齢である70歳以降の受診者は極めて 少なかったことから，前立腺癌に対する啓蒙活動がいまだ不十分であると思われた。ドック前立腺検診 による癌発見率は 16,125 名中 6 名， $0.04 \%$ でったが，年齢階層別にみると， 50 歳以上では 12,638 名中 6 名 $(0.05 \%), 60$ 歳以上では 2,513 名中 2 名 $(0.08 \%)$ ，受診者の年齢の上昇とともに発見率は高く なる傾向がみられた. PSAの sensitivity と specificity はそれぞれ $83.3 \%$ と $84.8 \%$ と高く, 実際検査法別 発見率は直腸診のみでは $0.01 \%$ あったのに対し, PSA 測定との併用では $0.15 \%$ と有意に高く（p< $0.01)$, ドック前立腺検診における PSA 測定の有用性が示唆された。前立腺癌確定者 6 名の病期は stage B 5 名, stage C 1 名と早期癌が多く, stage B 症例ではすべて根治的前立腺全摘除術が行われており, ドック前立腺検診の意義が示唆された。

キーワード：前立腺癌, ドック健診, 前立腺癌検診

\section{緒言}

近年, 社会の高齢化と生活環境の欧米化に伴い, 前 立腺癌は増加の傾向にある ${ }^{11}$. しかしながら前立腺癌 に対する一般の認識はいまだ低く, 患者の来院時, そ の大半は進行癌ないし転移癌の状態であり, 㤵蒙活動 と前立腺検診の普及の必要性が強調されている。前立 腺検診にはフィールド方式の集団検診と人間ドック健 診における前立腺検診のふたつがあるが, 集団検診に ついては1975年に京都府立医大グループが経直腸的超 音波断層診断装置を用いて本格的検診活動を開始して 以来 ${ }^{2)}$, 徐々に全国各地に拡がり, 成果があげられつつ ある3) 7). しかしながら, 人間ドック健診に打ける前立 腺検診の実体についてはいまだ十分把握されておら ず，どのような検査をどのような対象に行うべきかと いう基本的問題も明らかにされていないのが実情であ る.

今回我々は福岡県下におけるドック前立腺検診の実 態を明らかにする目的で, 過去 5 年間にわたる検診の 状況について調査を行い, その現状と問題点について 検討したので報告する。

\section{対象と方法}

1) 調查対象

1989年度において福岡県内の泌尿器科医が常勤する 総合病院は27施設であり，このうち人間ドック健診に 前立腺検診を組み込み施行していたのは13施設であっ た。今回はこのらち協力の得られた12施設（表 1)を
表 1 調査施設

\begin{tabular}{l}
\hline 九州厚生年金病院 \\
九州労災病院 \\
北九州総合病院 \\
健和会大手町病院 \\
新小倉病院 \\
新日鐵八幡製鐵所病院 \\
原三信病院 \\
九州中央病院 \\
国立福岡中央病院 \\
福岡赤十字病院 \\
自衛隊福岡病院 \\
聖マリァ病院 \\
\hline
\end{tabular}

対象として調査を行った。

2) 調查方法

1987年から1991年むでの過去 5 年間にわたる，人間 ドック健診受診者数, ドック前立腺検診の対象, 受診 者数, 検診の方法, 前立腺癌の確定者数およびその病 期, 治療法, 予後などについて調査を行い, 集計した。

\section{結果}

1. 検診方法

1991年において12施設中，ドック前立腺検診を人間 ドック健診受診者全員に行っていたのは 7 施設であ り，他の 5 施設では希望者のみに施行していた。年齢 
別にみると40歳以上男子をドック前立腺検診の対象者 としていたのが10施設であり，50歳以上としていたの は 2 施設にすぎなかった。これらの対象者に関する方 針はいずれの施設に扔いても過去 5 年間変更されてい なかった。

前立腺検診の方法の年次別变遷を図 1 に示す，直腸 診は 5 年間を通じて全施設で行われており, 腫瘍マー カーとしてPAPまたは総酸性フォスファターゼ （TACP）を併用する施設は1987年，1988年の各 2 施設 から1989年と1990年には各 3 施設へと増加したが, 1991年には 1 施設に減少しており，かわってPSAを 併用する施設が1987年, 1988年の各 1 施設から1989年, 1990年には各 2 施設，1991年には 4 施設と徐々に増加 する傾向にあった。直腸診は泌尿器科医が施行してい

図 1 前立腺検診法の年次別変遷

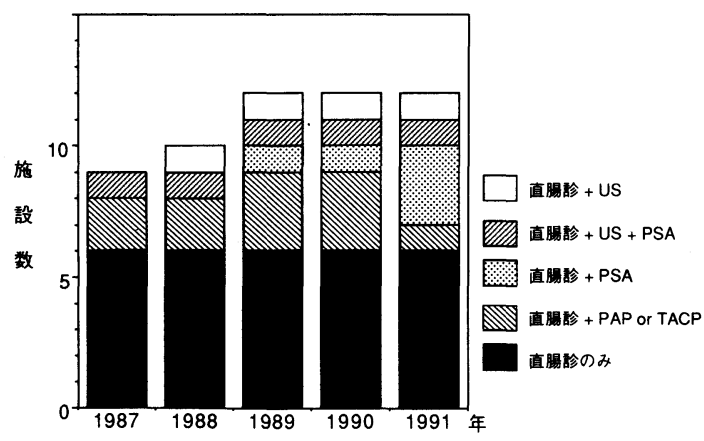

US:経直關的超音波断屈法 TACP:総酸性フォスファターゼ

図 2 前立腺検診受診者数の年次別変遷

\section{受診者数}

(人)

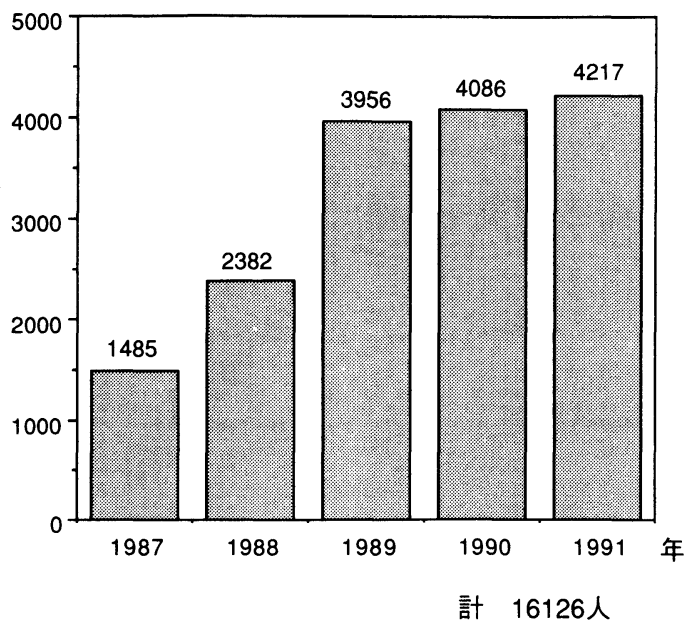

る施設が 8 施設，内科あるいは外科医が行っている施 設が 3 施設であり，他の 1 施設は1989年までは泌尿器 科医が施行していたが，その後内科医に変更されてい た。

2. 年次別受診者数

ドック前立腺検診受診者数の変遷を図 2 に示す. 12 施設に抢ける 5 年間のドック前立腺検診受診者総数は 16,126名で，これはこの間のドック健診受診者総数 37,098名の $43.5 \%$ に相当するものであった. 年次別で は1989年1,485名, 1988年 2,382 名, 1989年3,956名と著 名な増加がみられ，その後の 2 年間もわずかではある が増加の傾向がみられた。これは 1 施設あたりのドッ ク前立腺検診受診者数を年次別にみてもほぼ同様の傾 向であった。

しかしドック前立腺検診を希望者のみに行っている 5 施設における年次別前立腺検診受診者数およびドッ ク健診受診者数に対する割合をみると，希望して前立 腺検診を受ける人は毎年 1,000 名前後で,ドック健診受 診者の約 $20 \%$ 前後と低いレベルで一定していた（図 3 ).

3. 年齢階層別受診者数

12施設におけるドック前立腺検診の年齢階層別受診 者数は 50 歳代が 10,125 名 $(62.8 \%$ ) と最も多く, 次い で40歳代3,488名（21.6\%)，60歳代 2,311名（14.3\%） であり，70歳代は191名(1.2\%)，80歳代は11名(0.1\%) と極めて少数であった（図 4 ）。

図 3 前立腺検診受診者数の年次別変遷（希望者対象 施設)

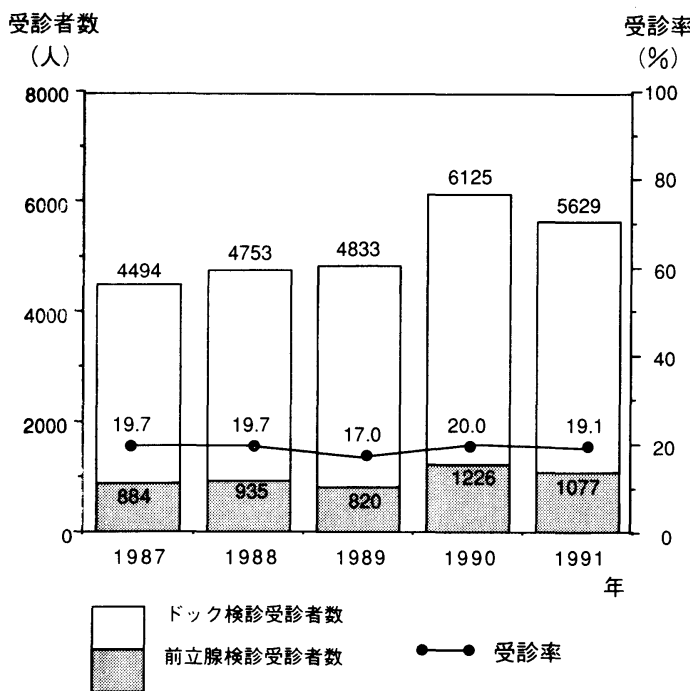


図 4 年齢階層別前立腺検診受診者数

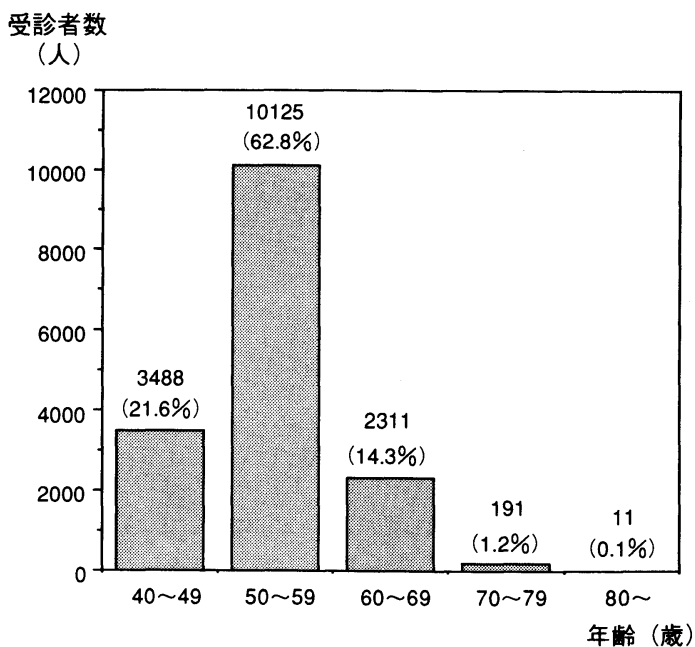

表 2 希望者を対象とした施設での年齢別検診受診者

\begin{tabular}{lcrl}
\hline 年齢 & ドック検診受診者 & 前立腺検診受診者 $(\%)$ \\
\hline $40 \sim 49$ & 11969 & 537 & $(4.5)$ \\
$50 \sim 59$ & 10621 & 3546 & $(33.4)$ \\
$60 \sim 69$ & 2872 & 773 & $(26.9)$ \\
$70 \sim 79$ & 352 & 81 & $(23.0)$ \\
$80 \sim$ & 20 & 5 & $(25.0)$ \\
\hline 計 & 25834 & 4942 & $(19.1)$ \\
\hline
\end{tabular}

希望者を対象としている 5 施設での年齢階層別受診 者数をみても, やはり 50 歳代の前立腺検診の受診者が 3,546 名 (33.4\%) と最も多く，60歳代以降の受診者数 は少なく，その受診率も25\%前後にすぎなかった（表 2).

\section{4. 前立腺癌の発見率}

ドック前立腺検診による前立腺癌の年次別発見率を 表 3 に示す。 5 年間全体では 16,126 名の受診者中 6 名 (0.04\%)に癌が発見されていたが，年次別の発見率に 特別の傾向はみられなかった。

年齢階層別の前立腺癌発見率は 60 歳代で 2,311 名中 2 名 $(0.09 \%)$ と最も高く，40歳代で癌が発見された ものはなかった(表 4)。 また，70歳代，80歳代は受診 者数が少なく, 癌は 1 例も発見されていなかった。し かし，これを年齢階層別に総合してみると，40歳以上 では 16,126 名中 6 名 $(0.04 \%), 50$ 歳以上では 12,638 名 中 6 名 $(0.05 \%), 60$ 歳以上では 2,513 名中 2 名 $(0.08 \%)$ の発見率となり，受診者の年齢の上昇とともに高くな る傾向がみられた。
表 3 前立腺癌の年次別発見率

\begin{tabular}{cccc}
\hline 年 & 前立腺検診受診者 & 前立腺癌症例 $(\%)$ \\
\hline 1987 & 1485 & 0 & $(-)$ \\
1988 & 2382 & 1 & $(0.04)$ \\
1989 & 3956 & 2 & $(0.05)$ \\
1990 & 4086 & 2 & $(0.05)$ \\
1991 & 4217 & 1 & $(0.02)$ \\
\hline 計 & 16126 & 6 & $(0.04)$ \\
\hline
\end{tabular}

表 4 前立腺癌の年齢別発見率

\begin{tabular}{|c|c|c|}
\hline 年齢 & 前立腺検猃受猃者 & 前立腺癌症例（\%) \\
\hline $40 \sim 49$ & 3488 & $0(-)$ \\
\hline $50 \sim 59$ & 10125 & $4 \quad(0.04)$ \\
\hline $60 \sim 69$ & 2311 & $2 \quad(0.09)$ \\
\hline $70 \sim 79$ & 191 & $0(-)$ \\
\hline $80 \sim$ & 11 & $0 \quad(-)$ \\
\hline 㖕 & 16126 & $6 \quad(0.04)$ \\
\hline 年歯 & 前立腺検診受診者 & 前立腺痘症例（\%) \\
\hline 40频以上 & 16126 & $6 \quad(0.04)$ \\
\hline 50歲以上 & 12638 & $6 \quad(0.05)$ \\
\hline 60 踣以上 & 2513 & $(0.08)$ \\
\hline
\end{tabular}

表 5 前立腺癌の検査方法別発見率

\begin{tabular}{|c|c|c|c|}
\hline 検査方法 & 前立腺検診受診者 & 前立腺㾤症例 & (\%) \\
\hline 直腸猃 & 9962 & $(0.01)$ & * \\
\hline 直腸診 + PSA & 1945 & $(0.15)$ & * \\
\hline 直腸䛦 + US & 1889 & $(0.05)$ & \\
\hline 直腸診 + TACP or PAP & 2569 & $(0.04)$ & \\
\hline 計 & 16126 & $(0.04)$ & \\
\hline
\end{tabular}

US:経直腸的超音波断層法、 TACP:総酸性フォスファターゼ、 *:p<0.01

検㚗法別の前立腺癌の発見率を表 5 に示す. 直腸診 のみによる発見率は $0.01 \%$ と最も低く, 一方直腸診+ PSA による発見率は $0.15 \%$ と最も高く, 両者の発見率 には有意差を認めた（ $\mathrm{p}<0.01 ， \chi^{2}$ test $)$.

癌を疑って生検あるいは吸引細胞診検査を施行した 症例における各種検查法の sensitivity, specificity, false positive rate, false negative rate を表 6 に示す. sensitivity は PSA が $83.3 \%$ と最も高く, 次いで直腸 診が $66.7 \%$ であり, PAP と経直腸的超音波断層法はい ずれも50\%であった。一方, specificityはPAPが $92.5 \%$ と最も高く, 次いで PSA が $84.8 \%$ であり，直腸 診と経直腸的超音波断層法はいずれも約 $30 \%$ と低かっ た。これらを反映して, false positive rateはPAP が $50 \%$ と最も低く, 次いで PSA 58.3\%であり, 直腸診と 
表 6 生検または吸引細胞診施行例での各検査所見

直腸部

\begin{tabular}{|c|c|c|c|c|c|}
\hline \multicolumn{4}{|c|}{ 生検／吸引細胞殓所見 } & & \multirow[b]{2}{*}{$66.7 \%$} \\
\hline 検查所見 & 癌あり & 癌なし & 計 & & \\
\hline 癌疑い & 4 & 36 & 40 & specificity & 32. \\
\hline 癌所見なし & 2 & 17 & 19 & false negative rate & $0.5-5-5 x-5$ \\
\hline 計 & 6 & 53 & 59 & false positive rate & 90. \\
\hline
\end{tabular}

経直腸的前立腺超音波断層法

\begin{tabular}{|c|c|c|c|c|c|}
\hline \multicolumn{4}{|c|}{ 生検／吸引細胞牾所見 } & \multirow[b]{2}{*}{ sensitivity } & \\
\hline 検查所見 & 㾔あり & 癌なし & 計 & & 50.0 \\
\hline 㾇疑い & 2 & 37 & 39 & & 3.5 \\
\hline 癌所見なし & 2 & 17 & 19 & false negative rate & \\
\hline 計 & 4 & 54 & 58 & false positive rate & \\
\hline
\end{tabular}

PAP

\begin{tabular}{|c|c|c|c|c|c|}
\hline & 生榙 $/ R$ & 田胞粀所 & & & \\
\hline 検查所見 & 癌あり & 癌なし & 計 & sensitivity & 50. \\
\hline 異常高值 & 3 & 3 & 6 & specificity & 92.5 \\
\hline 正常 & 3 & 37 & 40 & false negative rate & $7.5 \%$ \\
\hline 計 & 6 & 40 & 46 & false positive rate & 50.0 \\
\hline
\end{tabular}

PSA

\begin{tabular}{|c|c|c|c|c|c|}
\hline & \multicolumn{3}{|c|}{ 生検／吸引細胞彭所見 } & \multirow[b]{2}{*}{ sensitivity } & \multirow{2}{*}{$83.3 \%$} \\
\hline 検査所見 & 癌あり & 癌なし & 計 & & \\
\hline 異常高值 & 5 & 7 & 12 & specificity & 84.8 \\
\hline 正常 & 1 & 39 & 40 & egative rate & 2.5 \\
\hline 計 & 6 & 46 & 52 & false positive rate & 8. \\
\hline
\end{tabular}

経直腸的超音波断層法はいずれも約 $90 \%$ と極めて高 かった. false negative rateはいずれの検査法でも比 較的低く，特にPSA では $2.5 \%$ と極めて低いもので あった。

直腸診施行医別の前立腺癌の発見率は泌尿器科医が 行ら施設では $0.04 \%$ ，内科あるいは外科医が行ら施設 では $0.02 \%$ と有意差はないが泌尿器科医が行う施設の 発見率が高い傾向を示した（表 7 ）。

\section{5 . 前立腺癌確定者}

前立腺癌確定者 6 名の検診法，その後の検査所見, 病理組織学的分化度, 病期, 治療法, 予後を表 8 亿示 す. 検査所見では直腸診で 6 例中 4 例に癌を疑わせる 所見がみられていた。直腸診で癌が疑われなかった他 の 2 例のうち，1 例は PAP, PSA の腫瘍マーカーも正
表 7 前立腺癌の直腸診施行医別発見率

\begin{tabular}{lcc}
\hline \multicolumn{1}{c}{ 施行医 } & 前立腺検診受診者 & 前立腺癌症例 (\%) \\
\hline 泌尿器科医 & 11798 & $5(0.04)$ \\
内科医または外科医 & 4328 & $1(0.02)$ \\
\hline \multicolumn{1}{c}{ 計 } & 16126 & $6(0.04)$ \\
\hline
\end{tabular}

常範囲であり，経直腸的超音波断層法の久が癌を疑わ せる所見を呈していた。また，1例では直腸診，経直 腸的超音波断層法ともに癌を疑わせる所見はなく， PAP およびPSAのみが異常高值を示していた。

病理組織は高分化腺癌が 3 例, 中分化腺癌が 3 例で, 低分化腺癌はなかった。臨床病期は stage B が 5 例を 占めており，これらにはすべて根治的前立腺全摘除術 が施行されていた。他の 1 例は stage Cであり，ホル モン療法が行われていた。予後はホルモン療法を行っ ていた 1 例が消息不明であるが，他の 5 例は 1 年 6 カ 月から 3 年 9 カ月間生存中である.

\section{考察}

近年著明な増加傾向がみられる前立腺癌の治療にお ける重大な問題のひとつは, 患者の大半が進行癌ある いは転移癌といら状態で発見されるために根治的治療 を行える症例が少ないといらことである。このような 進行前立腺癌に対する治療としてはホルモン療法が第 1 選択となり，すぐれた治療効果を示すことが知られ ているが，その制癌効果に限界があることも事実であ り，長期的にみると必ずしも十分な延命効果が得られ てはいない。

癌治療の根本は早期発見, 早期治療であり, 前立腺 癌においても近年早期発見のための検診活動が行われ るようになってきた。集団検診がそのひとつであり， 前立腺検診協議会による1989年までの全国16施設の集 計では 35,504 名の第 1 次検診受診者中前立腺癌は 252 名 $(0.71 \%)$ に発見されたことが報告されている77. こ れは胃癌検診での胃癌発見率が 1,000 対 1.39 , 子宮癌検 診での子宮癌発見率が1,000対1.76から1.25である8)

表 8 前立腺癌症例

\begin{tabular}{|c|c|c|c|c|c|c|c|c|c|c|}
\hline 年齡 & 発見年次 & 㭘査法 & DRE所見 & US所見 & PAP & PSA & 分化度 & 臨床病期 & 治療 & 予後 \\
\hline 59 & 1987 & $D R E+P A P$ & 㾇疑 & 疝疑 & 1.5 & $4.5 \uparrow$ & 高 & B & RP & 生存（45力月） \\
\hline 59 & 1988 & DRE & 癌疑 & 施行せず & $8.2 \uparrow$ & $11.3 \uparrow$ & 高 & C & $\mathrm{HT}$ & 不明 \\
\hline 66 & 1988 & $\mathrm{DRE}+\mathrm{PSA}$ & 癌疑 & 異常なし & 1.5 & $4.6 \uparrow$ & 高 & B & RP & 生存（36力月） \\
\hline 55 & 1990 & DRE+US & 異常なし & 癌疑 & 1.8 & 2.0 & 中 & B & RP & 生存（35力月） \\
\hline 56 & 1990 & $D R E+P S A$ & 異常なし & 翼常なし & $7.7 \uparrow$ & $25.7 \uparrow$ & 中 & B & RP & 生存（29力月） \\
\hline 51 & $1991^{\circ}$ & $\mathrm{DRE}+\mathrm{PSA}$ & 癌疑 & 㿎疑 & $3.2 \uparrow$ & $22.2 \uparrow$ & 中 & B & $\mathrm{RP}$ & 生存（18力月） \\
\hline
\end{tabular}


ことを考えると，極めて良好な発見効率である。しか もその病期は stage B 132例 (52\%), stage C 52例 (20\%)， stage D 53例 (21\%)，不明15例と通常発見さ れる前立腺癌とは逆に早期癌が大半を占めることか ら，着実に成果があげられつつあるといえる。しかし ながらこれらの集団検診は特定地域に招いて，地区医 師会, 市町村等地方公共団体などの協力のもとに汪と んどボランティア活動として進められているものであ り，急速な全国的普及を計ることはなかなか困難であ る。事実，1975年に京都府立医大で集団検診が開始さ れて以来 ${ }^{2)}$ ，1986年の前立腺研究財団の設立もあって， 徐々に検診を行らグループは増えつつはあるものの,

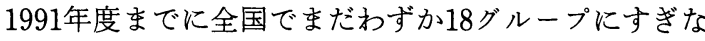
(.7).

一方，検診活動のひとつとしての人間ドック健診に おいても中高年男子の検査対象として前立腺をとりあ げるよらになれば，前立腺癌早期発見のらえで十分成 果をあげ得るものと期待される。しかも前立腺検診協 議会によるドック前立腺検診の実態についての全国調 查ではドック健診で前立腺検查を行う施設は 1975 年頃 から急激に増加する傾向にあり, 1989年には調查518施 設中 292 施設 $(56.4 \%)$ 飞達していることが示されてお り7)，集団検診に比べて普及をはかりやすいと考学ら れる。福岡県においても同じ1989年に泌尿器科医が常 勤している総合病院 27 施設中人間ドックに前立腺検診 を組み込み施行している施設は13施設（48.1\%）であ ク，その割合は浪全国の調査結果と同様であった。 今回の調査はこのらち協力の得られた12施設を対象に 行ったものである.

福岡県におけるドック前立腺検診受診者総数および 1 施設あたりの受診者数は年々増加の傾向にあり，こ れは一見一般成人のみならず病院側の前立腺癌に対す る認識が高まりつつあることを示唆するもののように も思えた。しかしながらその年齢階層別受診者数をみ ると 50 歳代が $63.6 \%$ と過半数を占め, 次いで60歳代 14.3\%であり, 最も前立腺検診が望まれる70歳代の前 立腺癌好発年齢層の受診率がわずか $1.2 \%$ と極めて低 い点は問題である。しかも希望者のみをドック前立腺 検診の対象としている施設に打ける前立腺検診受診者 の割合は最近 5 年間, ドック健診受診者の $20 \%$ 前後と 低いレベルで一定しており，またその受診年齢層もや はり50歳代に多く，60歳代以降の受診率は $25 \%$ 前後に 過ぎなかったことは前立腺癌に対する啓蒙がいまだ不 十分といわざるを得ず一層の努力が必要と思われた。
過去 5 年間の 12 施設における前立腺癌の発見率は ドック前立腺検診受診者 16,126 名中 6 名 $0.04 \%$ であっ たが，これは集団検診による発見率2) 7)に比べて明ら かに低いものであった。これはドック前立腺検診では その受診者層が集団検診に比べて比較的若いことや集 団検診に损いては何らかの自覚症状を有する人が受診 する割合がドック前立腺検診に比べて多いためではな いかと推定される，他施設に抢けるドック前立腺検診 による癌発見率との比較では大阪府立成人病センター に掞いては1977年から1983年までの 17 年間に 50 歳以上 の男子 2,786 名中 7 名 $(0.25 \%)$ とい5高率に前立腺癌 を発見している ${ }^{4)}$.さらに, 1989年度のドック前立腺検 診に関する全国集計では 42,924 名中 37 名 $(0.086 \%)^{7)}$ に前立腺癌が発見されて扣り，いずれも我々の発見率 に比べて高いものであった。

前立腺検診の意義はいわゆる無症状の早期前立腺癌 の発見にあると考光られる。わが国の剖検例に括ける ラテント癌の発見率は50歳未満では極めて低いが， 50 歳以上では約 $20 \%$ に達することが報告されてい $3^{9) \sim 11)}$. 今回の調查で確定した前立腺癌 6 例の平均年 齢は57.7歳と比較的若い年齢層であったが，これは70 歳以上のドック検診受診者が極端に少ないためと考兄 られ，年齢階層別癌発見率からみるとやはり年齢の上 昇とともに発見率も上昇する傾向であった。 40 歳代の 癌確定者は537名の検診受診者中皆無であり,ドック前 立腺検診の対象としては50歳以上男子でよいと思われ る. また, ラテント癌は臨床癌に比べて, 病理組織学 的分化度が高いといわれているが10112)，今回の調査で は高分化腺癌は 6 例中 3 例にすぎなかった。

ドック前立腺検診の方法については直腸診は全施設 で行われていたが, 前立腺癌の発見率は泌尿器科医が 施行する施設の方が他科医師が施行する施設に比べて 高い傾向があった。これは泌尿器科医以外の医師が直 腸診を行ら施設ではそれだけ前立腺癌に対する病院側 の認識が低く, 前立腺癌を発見しようという熱意も低 いことを反映した結果と考えられ，ドック検診への泌 尿器科医の積極的取り組みが必要と思われた。

各種検査法の有用性を sensitivity, specificity, false positive rate, false negative rateの面からみると, 直腸診と経直腸的超音波断層法は specificity がいず れも約 $30 \%$ と低く, false positive rate はいずれも約 $90 \%$ と極めて高かったが，これはマーカーと異なりこ れらの検查には多少とも主観的な要因が加わるため, 癌を見逃すことなく, 少しでも疑わしいものは拾い上 
げようという意識のあらわれであろうと思われる。し かし，それにもかかわらず， sensitivityはそれぞれ 66.7\%，50.0\%とPSA の83.3\%にははるかに及ぼな かったことはこれらの検査のみでは screening 上限界 があると思われる。マーカーとしてのPAPは specificity が最も高く, false positive rate は最も低 かったが, sensitivityは最も低く, 癌の早期発見には 不向きと思われる。一方, PSA は従来からいわれてい るよらに洸, sensitivityが最も高く, false negative rateは最も低かったが, 今回の調査では specificity も PAPには若干劣るとはい光, $84.8 \%$ と比較的良好で あった。実際直腸診のみと直腸診+PSA に上る癌発見 率の間にも有意差を認めており，ドック前立腺検診に 扮けるPSAの有用性が示唆された。経直腸的超音波 断層法に関してはこれが有用であった症例もあるが， 明らかな癌発見率の向上は得られておらず，人間ドッ ク健診は限られた日程のなかでの全身チェックである こと,さらには検診にとらわれる医師の時間的制約, 受診者の費用などを考慮すると，オプションとして受 診者が希望する場合に行らのでよいと思われる。した がって我々は現時点に拈けるドック健診に扮ける前立 腺検診の方法としては泌尿器科医が確実に直腸診を行 い, 時間的, 身体的負担の少ないPSA 測定を併用する 方法で良いと考光る。しかし今回の調査では生検ある いは吸引細胞診を行った59例すべてに上記 4 種類の検 査が行われていたわけではなく, 有用性を比較するに は対象が各検査毎に若干異なる点, 多施設での調査の ために直腸診や経直腸的超音波断層法は診断技術に差 があると思われる点, 癌確定者がわずか 6 名と極めて 少ない点等の問題があり, 今後さらに多数例での検討 が必要と思われる。また，もし直腸診のみを行ってき た施設に沶いて新たに PSA 測定を組み込むには既存 の検查を何か削除するかあるい健診費用を引き上げ ざるを得ず, 病院内での啓蒙活動も一層重要になると 思われる。

直腸診とPSA 併用による癌発見率は1,945名中 3 名であったが，仮に PSA の測定費用を 1 検体 2,000 円 とすると，1名の前立腺癌発見に要した費用は約 130 万 円ということになり，これはフィールド方式の集団検 診の場合の50７0万円(6)14! に比べて割高である。しか し今回の調査においてドック検診で発見された前立腺 癌患者の平均年齢は 57.7 歳と, 通常の前立腺癌患者の 初診時年齢15)やフールド方式の集団検診で発見され る前立腺癌患者のそれ(2) 6) と比べて明らかに若く, し
かもその病期は stage B 5 例, stage C 1 例と早期癌 が多く, stage B では全例に根治的前立腺全摘除術が 施行されていたこと等を考慮すれば，十分意義深いも のと思われる。

今後前立腺癌に対する啓蒙活動を病院内外で広く行 い, 検診対象を50歳以上の男性にしぼり, 泌尿器科医 による直腸診に PSA 測定の併用を採用していく施設 が増えれば，さらに早期前立腺癌を効率良く発見する ことが可能になるものと思われる。

\section{文献}

1）志田圭三：前立腺癌の疫学. 臨床病理と診断. 臨床 病理, $68,1-9,1986$.

2) 渡辺 決, 三品輝男, 大江 宏, 斉藤雅人: 前立腺 の集団検診. 日本医事新報, 2830, 28-31，1978.

3）古屋聖児, 横山英二, 熊本悦明, 青木正治, 田仲紀 明：寒冷地に拈ける前立腺肥大症㧍よび前立腺癌 の発生頻度に関する研究。日泌尿会誌, 76, 957-964, 1985.

4）志田圭三：前立腺検診…中高年男子成人病対策の ために一。前立腺研究財団, 1987.

5) Imai, K., Zinbo, S., Shimizu, K., Yamanaka, H., Kumasaka, F. and Sato, Z.: Clinical characteristics of prostatic cancer detected by mass screening. Prostate, 12, 199-207, 1988.

6) 内藤誠二, 加治慎一, 松本哲朗, 熊澤浄一, 蓮尾 裕, 上田一雄, 藤島正敏 : 福岡県粕屋郡久山町に拉 ける前立腺集団検診. 日泌尿会誌, 81, 1844-1848, 1990.

7）人間ドック健診における前立腺検查調查報告 -1989 年度一. 前立腺検診協議会, 1991.

8）国民衛生の動向．厚生の指標，臨明増刊，p. 107 -110 , 厚生統計協会, 東京, 1986.

9) Yatani, R., Chigusa, I., Akazaki, K., Stemmermann, G.N., Walsh, R.A. and Correa, P.: Geographic pathology of latent prosttic carcinoma. Int. J. Cancer, 29, 611-616, 1982.

10）和田鉄郎：最近の日本人の前立腺潜伏癌（ラテン 卜癌）の臨床病理学的検討. 日泌尿会誌, 78, 2065-2070, 1987.

11) Akazaki, K. and Stemmermann, G.N. : Compatitive study of latent carcinoma of the prostate among Japanese in Japan and Hawaii. J. Natl. Cancer Inst., 50, 1137-1144, 1973.

12）三須良彦：日本人に扮ける潜伏性前立腺癌の研 究. 癌の臨床, 7, 304-320, 1961.

13）秋元 晋, 赤倉功一郎, 島崎 淳：前立腺癌に拈け る腫瘍マーカー(前立腺酸性フォスファターゼ, $\gamma$ セミノプロティン, 前立腺特異抗原)の検討. 泌尿 紀要, 34, 1389-1396, 1988.

14）熊坂文成, 清水嘉門, 神保 進, 佐藤 化: 前立腺 
検診体系に関する研究. 北関東医学, 37, 179-195, 1987.

15）赤倉一郎, 井坂茂夫, 布施秀樹, 秋元 晋, 今井強 一, 山中英寿, 赤座英之, 新島瑞夫, 森山信男, 河 邊香月, 松本恵一, 手嶋伸一, 古畑哲彦, 武田 尚,
藤井 浩, 近藤猪一郎, 古武敏彦, 宇佐美道之, 松 村陽右, 島崎 淳: 本邦における前立腺癌の治療 動向 : 最近 5 年間に拈ける 9 施設の統計. 泌尿紀 要, 34, 123-129, 1988 .

（1993年 2 月 9 日受理） 